 \\ Onset of an Aptian carbonate platform overlying a Middle-Late Jurassic radiolaritic-ophiolithic mélange in the Mirdita Zone of Albania
}

\author{
Felix Schlagintweit ${ }^{1}$, Hans-Jürgen Gawlick², Richard Lein ${ }^{3}$, Sigrid Missoni² \\ and Lirim Hoxha ${ }^{4}$ \\ ${ }^{1}$ Lerchenauerstr. 167, D-80935 Munich, Germany; (ef.schlagintweit@t-online.de) \\ ${ }^{2}$ Department of Applied Geosciences and Geophysics, Chair of Prospection and Applied Sedimentology, \\ University of Leoben, Peter-Tunner-Strasse 5,A-8700 Leoben, Austria; (gawlick@unileoben.ac.at; s.missoni@. \\ daad-alumni.de) \\ ${ }^{3}$ University Vienna, Center for Earth Sciences, Althanstr. 14, A-1090 Vienna, Austria; (richard.lein@univie.ac.at) \\ ${ }^{4}$ Empire Mining Albania (Empire Mining Corporation) Rruga Perlat Rexhepi, Pallati Unikon, Kati i VI-te Ap. 28, \\ Tirana, Albania; (1.hoxha@yahoo.com)
}

doi: $104154 / \mathrm{gc} .2012 .02$

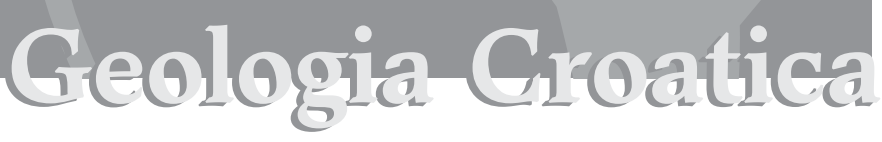

\begin{abstract}
Late Jurassic and Early Cretaceous carbonate sediments of different age and facies form the post-emplacement settings on top of the Mirdita Ophiolite Zone in northern Albania. They seal the early Late Jurassic emplacement of the ophiolite nappes, and are the only datable relics overlying the ophiolites. They aid evaluating the different tectonic movements associated with uplift and erosion as well as sea-level fluctuations during that time span. These carbonates overlie ophiolite-derived clastics very often as shallowing-upward sequences. One of the largest shallow-water platforms is the Mali I Shenjtit platform, previously assigned to the Barremian-Aptian. A well-preserved section at the base of the platform can be ascribed to the Early-Late Aptian based on orbitolinid foraminifera together with dasycladalean algae. This carbonate platform is the youngest preserved Early Cretaceous platform in Albania, but was largely eroded away. Late Cretaceous shallow-water rudist limestones are widespread and preserved in the Dinaride-Albanide-Hellenide realm directly above an eroded older basement. Therefore, this Aptian platform is very important for the reconstruction of the Early Cretaceous palaeogeography in the northwestern Neotethyan realm. In addition, the stratigraphic ranges of characteristic Aptian orbitolinid foraminifera, Rectodictyoconus giganteus SCHROEDER and Mesorbitolina texana (ROEMER), are discussed on the basis of these results.
\end{abstract}

Keywords: Mirdita Ophiolite Zone, Platform Carbonates, Early Cretaceous, Neotethys Realm

\section{INTRODUCTION AND GEOLOGICAL SETTING}

The onset of carbonate platforms in tectonically active mountain ranges like the Albanides (Fig. 1) plays an important role in the reconstruction of the evolution of orogenic belts. The Mirdita zone in Albania consists of obducted Triassic-Jurassic ophiolites, which derived, according to the Triassic shelf arrangement, from the Neotethys Ocean further to the east (GAWLICK et al., 2008), comparable with the ophiolites in the Dinarides (SCHMID et al., 2008; GAWLICK et al., 2009). For a different palaeogeographic interpretation see e.g.: ROB-
ERTSON \& SHALLO (2000), DILEK et al. (2005); ROBERTSON et al. (2011). These ophiolites and the accompanying ophiolitic mélanges (radiolaritic-ophiolitic (wild-)flysch in the sense of GAWLICK et al., 2008), were overlain by several carbonate platforms of different ages, that sealed the emplacement of the ophiolite nappe stack and their obduction onto the Apulian lower plate in Oxfordian times. These platforms allow to reconstruct the post-emplacement history of the ophiolite nappes (e.g., ongoing tectonic movements, sealevel changes). The oldest proven platform is represented by the Kimmeridgian-Tithonian Kurbnesh carbonate platform 


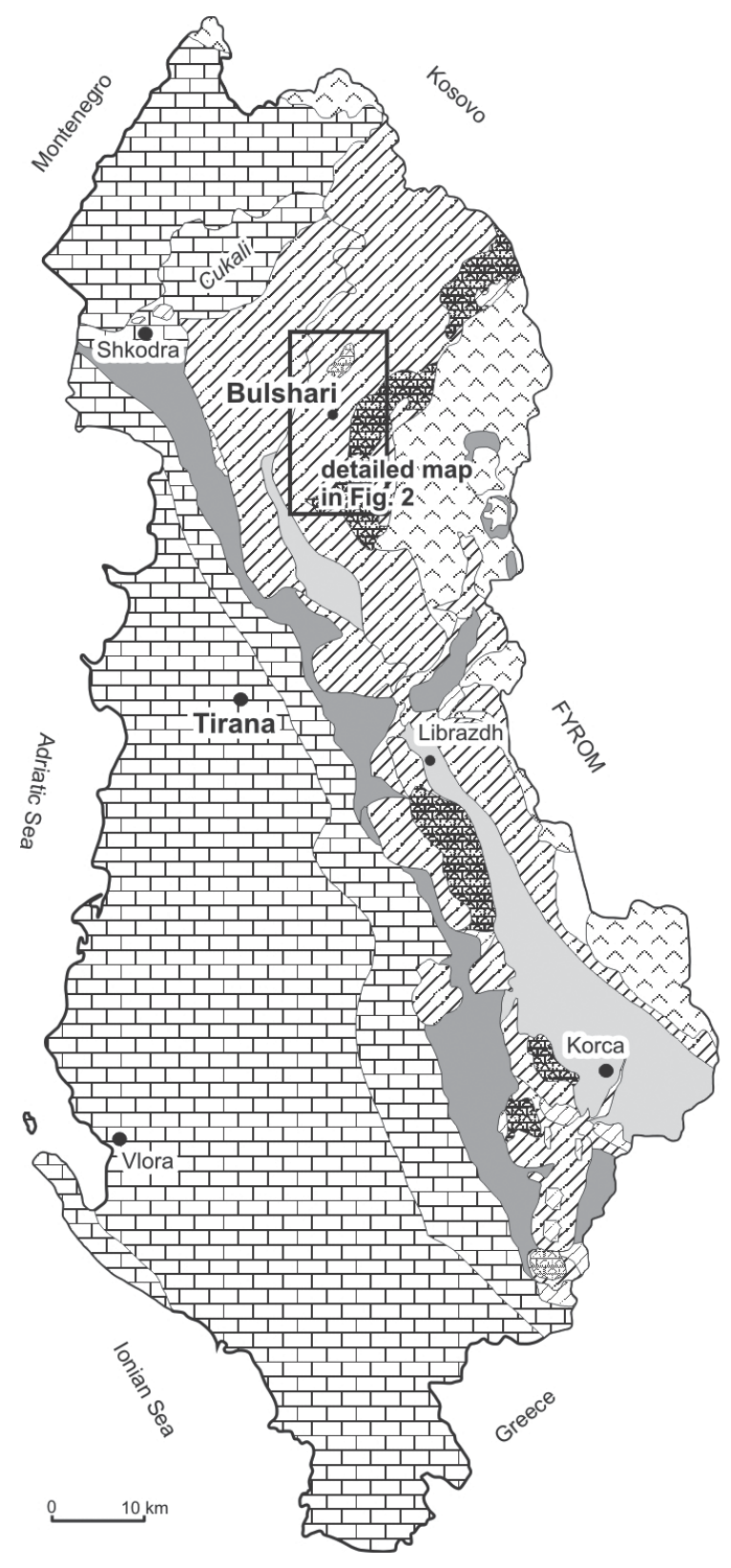

Molasse sediments and Neogene-Quaternary sediments

Maastrichtian to Eocene flysch

Internal Albanides

\section{Mirdita Ophiolite Zone}

EDP

Ophiolites + metamorphic sole and associated sediments; radiolariticophiolitic (wild)flysch (Mélange), (Bathonian-Oxfordian) and flyschoidmolasse (Kimmeridgian-Valanginian)

Transgressive Cretaceous limestone

External Albanides

Figure 1: A simplified tectonic map of Albania (after NOWACK, 1928; XHOMO et al., geological map of Albania 2002) and the study area.

(SCHLAGINTWEIT et al., 2008), which was eroded in Early Cretaceous (Berriasian - Valanginian) times. After erosion of the Kurbnesh platform, the ?Late Berriasian-Valanginian
Munella carbonate platform was established (PEZA \& MARKU, 2002; GAWLICK et al., 2008) in a tectonically active regime (SCHLAGINTWEIT et al., 2008; ROBERTSON et al., 2011). The Munella platform (e.g., in the regions of Mali I Munelles, Mali I Shenjtit - Fig. 2) in addition to the younger Mali I Shenjtit platform, represents the only autochthonous Early Cretaceous shallow-water carbonate platform in the area of the Mirdita Zone, covering large areas in central Albania. Both platforms were originally seen as one platform and were dated by PEZA \& MARKU (2002) and PEZA \& ZITT (2002) as Barremian to Aptian in age. GAWLICK et al. (2008) subdivided this platform into representing two stages of shallowwater carbonate deposition, the older Munella carbonate platform (?Late Berriasian to Valanginian) and the younger Mali I Shenjtit platform (?Late Barremian to Aptian). Like the Late Jurassic Kurbnesh platform, the Munella carbonate platform was eroded in most areas. The next carbonate platform was established after this deep erosion in ?Barremian or Aptian times (GAWLICK et al., 2008). Nevertheless, the exact age of the onset of the Mali I Shenjtit platform has remained enigmatic, but is very important for the manifestation/correlation of tectonic events or sea-level fluctuations in the whole Dinaridic-Albanide-Hellenide realm.

West of Bulshari (Fig. 2), the Bathonian to Oxfordian radiolaritic-ophiolitic (wild)flysch (mélange) (Perlat Formation: GAWLICK et al., 2008) and the overlying ?Early Cretaceous conglomerates are followed by the onset of the Mali I Shenjtit carbonate platform (Fig. 3). At the base of the investigated section (Fig. 4), directly on top of the mélange, a sequence of ophiolite-derived clastics (some tens of metres thick) is preserved (e.g., north of Konaj: Fig. 2). This succession is overlain by a marine carbonate succession with a preserved shallowing-upward sequence.

This paper describes the early evolution of the youngest Early Cretaceous platform in Albania together with new biostratigraphic and microfacies data. The results are important for the exact timing of ongoing tectonic movements in the Dinaride-Albanide mountain chain and to close a gap in knowledge of the age of the onset of different shallow-water carbonates above the Mirdita Ophiolite Zone.

\section{SEDIMENTOLOGY, STRATIGRAPHY, AND MICROPALAEONTOLOGY}

\subsection{Microfacies and micropalaeontology of the resediments}

The microfacies of the mass-flows are represented by different types of packstones with bio- and lithoclasts of varying size and degrees of sorting. Some clasts are close-packed with stylolitized contacts. This fitted fabric corresponds to the stylobreccia fabric of LOGAN \& SEMENIUK (1976) (Fig. 5a). Sorting of the subangular clasts in these breccias is poor. The stylobreccia may directly overlie wackestones with dispersed larger litho- and bioclasts, mainly skeletons of stromatoporoids and small globigerinid and globigerinelloid foraminifera (Fig. 5a-b, f). The stromatoporoids belong to two taxa, Tubuliella fluegeli TURNŠEK (Figs. 6i) and Tubuliella 


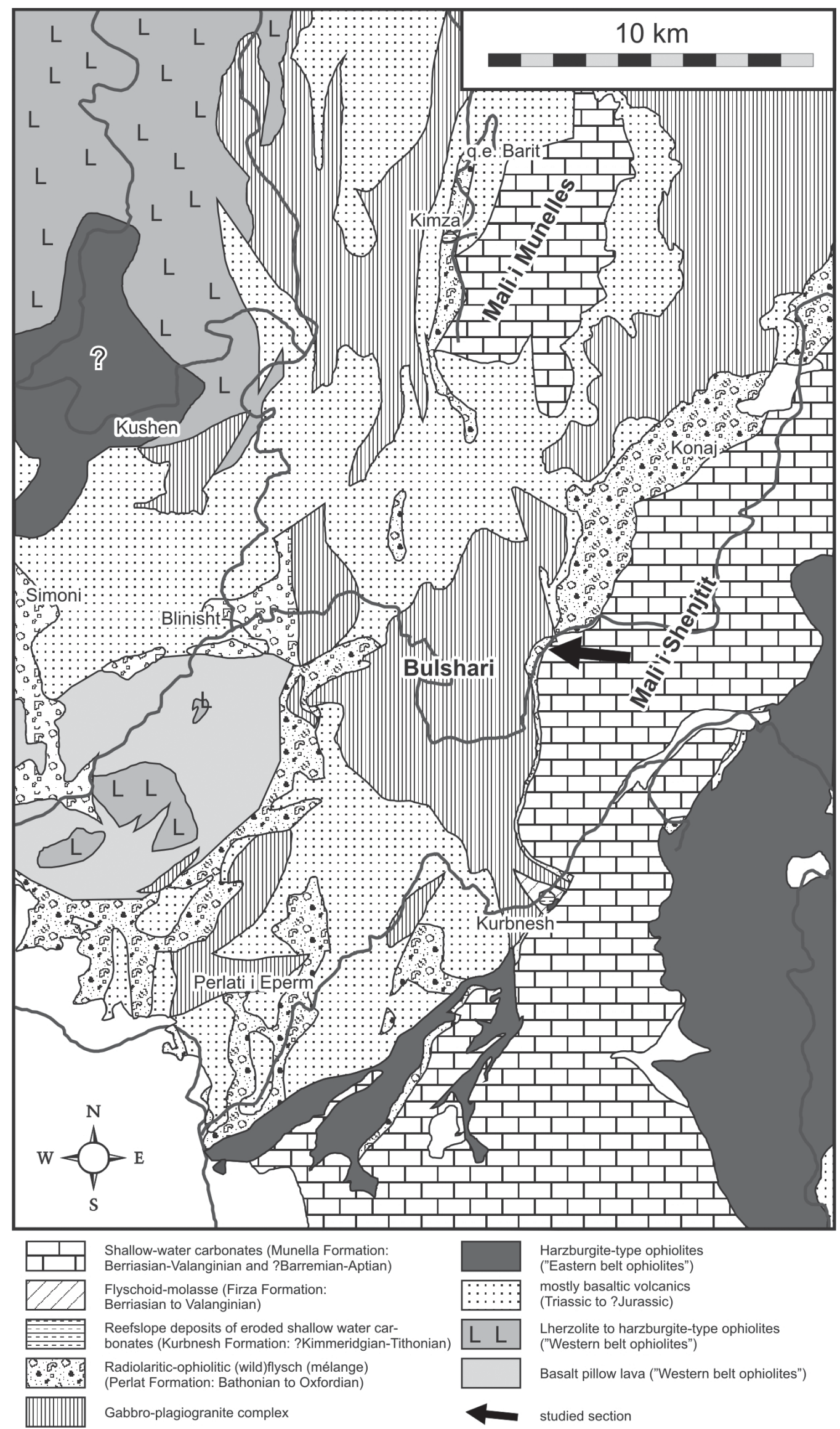

Figure 2: The Mali i Shenjtit carbonate platform and the Munella carbonate platform (Mali I Munelles) in the northern/central Mirdita zone. Simplified geological map on the basis of the Harta Gjeologjike e Shqiperise $1: 200.000$ (XHOMO et al., 2002), redrawn with the integration of the present results (after GAWLICK et al., 2008; SCHLAGINTWEIT et al., 2008). The studied section is located west of the village of Bulshari. 


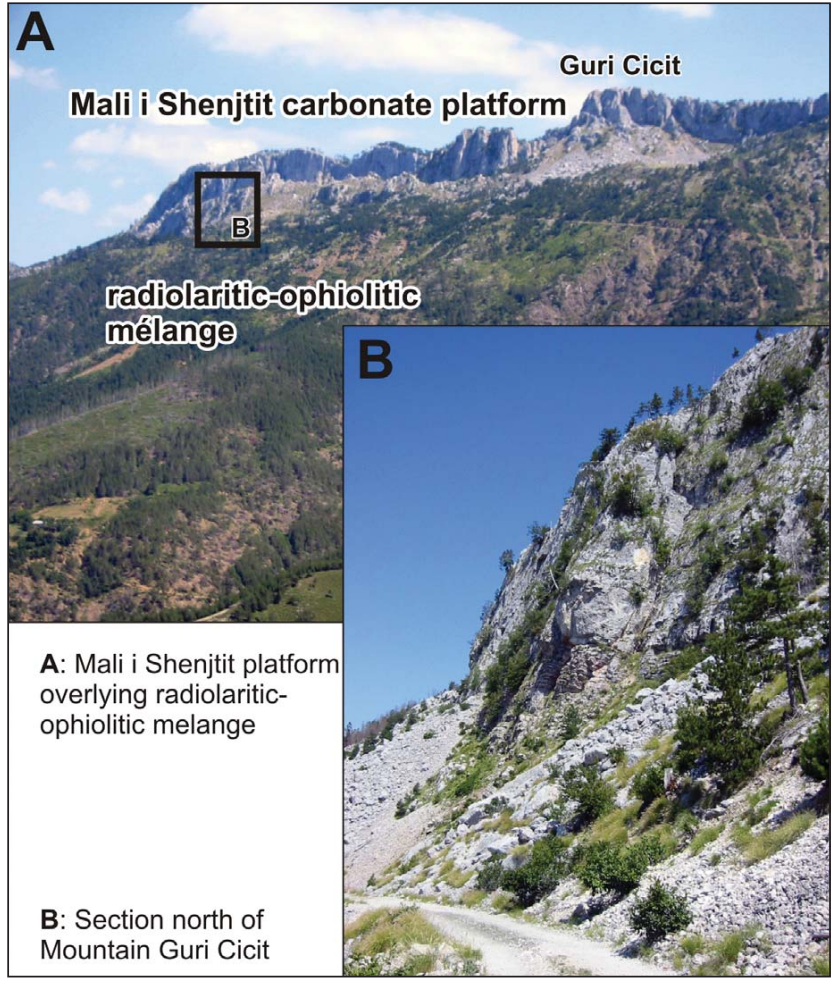

Figure 3: A) Field view of the Mali I Shenjtit carbonate platform overlying the Jurassic radiolaritic-ophiolitic mélange, in the upper part with ?Early Cretaceous deep-water conglomerates. B) Studied section north of Mountain Guri Cicit showing a shallowing-upward sequence, which reflects a prograding platform.

rotunda TURNŠEK (Fig. 6j), so far only known from the Late Jurassic of Slovenia (TURNŠEK, 1966), Croatia (MILAN, 1969) and Albania (SCHLAGINTWEIT et al., 2008). Tubuliella is a typical representative of the so-called actinostromariid zone, characterizing the outer zone of Late Jurassic barrier-type reef complexes along shelf margins (TURNŠEK, 1969; TURNŠEK et al., 1981), thus explaining their resedimentation along a presumably rather steep slope, and their occurrence in the investigated mass-flows. The new Aptian findings also provide clear evidence that the two taxa have broad stratigraphic ranges. Typical microencrusters such as Radiomura cautica SENOWBARI-DARYAN \& SCHÄFER (Figs. 5c, 6b) and Crescentiella morronensis (CRESCENTI) (Fig. 6a) also occur in accordance with the inferred original platform margin setting of the resedimented limestones.

Beside this, the packstones contain Dasycladalean algae: Triploporella sp., Acroporella radoicicae PRATURLON (Fig. 6d), Linoporella/Steinmanniporella sp. (Fig. 6g) and Steinmanniporella? parsica TAHERPOUR KHALIL ABAD et al. (Fig. 6e, h). This taxon was described recently from the Aptian of Iran (TAHERPOUR KHALIL ABAD et al. 2010). Higher up in the section, grain- to rudstones occur with dasycladalean algae and orbitolinid foraminifera. The two taxa characterizing this interval are Rectodictyoconus giganteus SCHROEDER (Fig. 7a-c) and Mesorbitolina texana (ROEMER) (Fig. 7d-f) being of importance for the biostratigraphic dating of the section (Fig. 8).

\subsection{Biostratigraphy}

Discussion of the biostratigraphy of Aptian strata, requires recognition that some authors use a bipartite division (Bedoulian = Early, Gargasian + Clansayesian = Late Aptian) (e.g., SCHROEDER et al., 2010) while others prefer a tripartite division $($ Bedoulian $=$ Early, Gargasian $=$ Middle, Clansayesian = Late Aptian) of the stage (e.g., CASTRO et al., 2002; GRADSTEIN et al., 2004). MASSE (2003) additionally distinguished a Lower ?Early Bedoulian (Deshayesites tuarkyri$c u s+$ D. weissi ammonite zones) and an Upper ?Late Bedoulian (D. deshayesi + Dufrenoya furcata ammonite zones).

The stratigraphy of the studied section is based on orbitolinid foraminifera (e.g., SCHROEDER, 1964, 1985; CHERCHI \& SCHROEDER, 1999; SCHROEDER et al., 2002) (Fig. 7a-f). Supporting data are available from dasycladalean algae (e.g., GRANIER \& DELOFFRE, 1993; BUCUR, 1999) and other benthic foraminifera. The two biostratigraphically most important taxa are Rectodictyoconus giganteus SCHROEDER (Fig. 7a-c) and Mesorbitolina texana (ROEMER) (Fig. 7d-f). R. giganteus was described by SCHROEDER (1964) from the Urgonian of Spain. Zone II with $R$. giganteus was considered to belong to the Barremian. Following Zone I with Palorbitolina lenticularis, (also characterizing Zone IV of SCHROEDER 1964), a Late Barremian age was originally assumed. In subsequent works, this age was corrected, with $R$. giganteus having its first appearance (FAD) in the earliest Aptian (e.g., CHERCHI \& SCHROEDER, 1999; SCHROEDER et al., 2002, fig. 1; SCHROEDER et al. 2010, fig. 3). The total taxon range should be restricted to the lowermost part of the Early Aptian (Bedoulian) (e.g., SCHROEDER, 1964, fig. 1; SCHROEDER et al., 2010, fig. 3). Reviewing the literature, MASSE (2003), concluded that $R$. giganteus is a Bedoulian marker and that data from Spain suggests its essentially lower ?early Bedoulian range. The taxon range zone of Mesorbitolina texana is often indicated as Late Aptian (= Clansayesian) to Middle Albian (SCHROEDER, 1975, 1985; VELIĆ, 2007). A thorough analysis of different sections in Spain with orbitolinids, planktonic foraminifera and ammonites (CASTRO et al., 2002, fig. 3) has shown, that $M$. texana reaches down to the upper part of the Gargasian within the Globigerinelloides algerianus planktonic foraminifera zone (= upper part of the Parahoplites melchioris ammonite zone, compare Fig. 6 in ROPOLO et al., 2008). In a new biostratigraphic scheme of Barremian-Albian orbitolinids, the first occurrence of Mesorbitolina texana is indicated as the middle part of the Gargasian (base of the P. melchioris ammonite zone) (SCHROEDER et al., 2010).

Our results are partly in contradiction to the generally accepted stratigraphic considerations according to SCHROEDER (1964), that $R$. giganteus and $M$. texana or also $M$. parva (Gargasian-Lowermost Clansayesian acc. to SCHROEDER et al., 2010), should not display overlapping ranges. In the studied section, the basal part, up to sample AL 972 only contains $R$. giganteus, followed by an interval $(\sim 17 \mathrm{~m})$ where $R$. giganteus co-occurs with $M$. texana in the same thin-sections (AL 972 to AL 980) (see Fig. 4). As the two species occur as both isolated bioclasts, and within lithoclasts that have been contemporaneously resedimented, reworking 
Section north of Mountain Guri Cicit

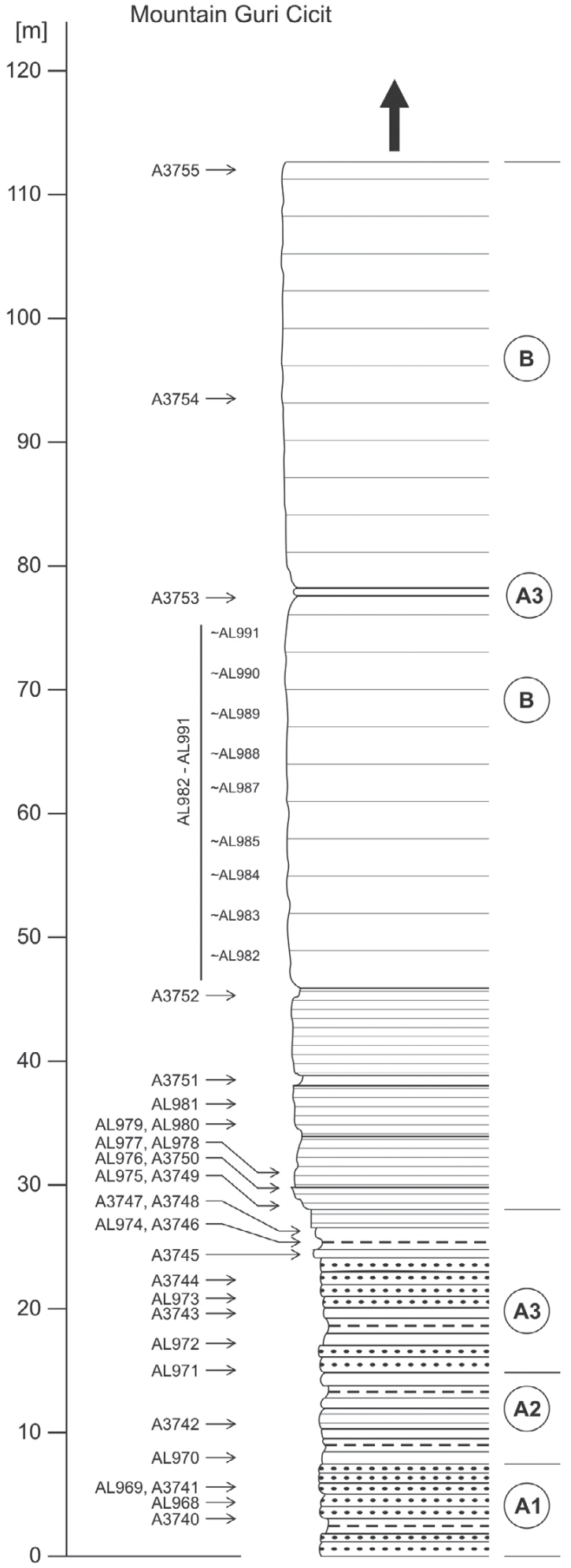

\section{(1)}

\begin{tabular}{|c|c|c|}
\hline Foraminifera & Calcareous Algae & Others \\
\hline 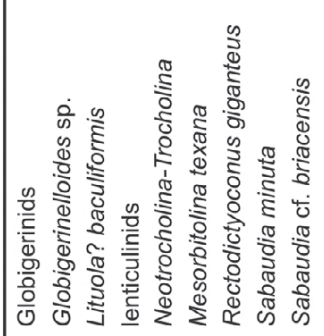 & 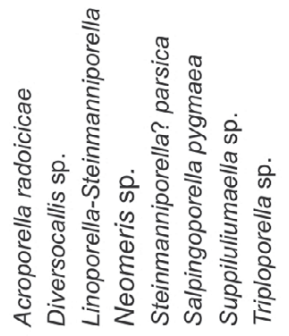 & 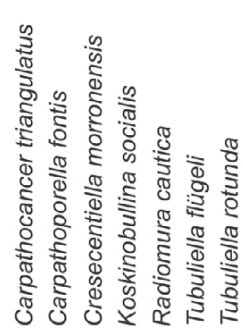 \\
\hline
\end{tabular}
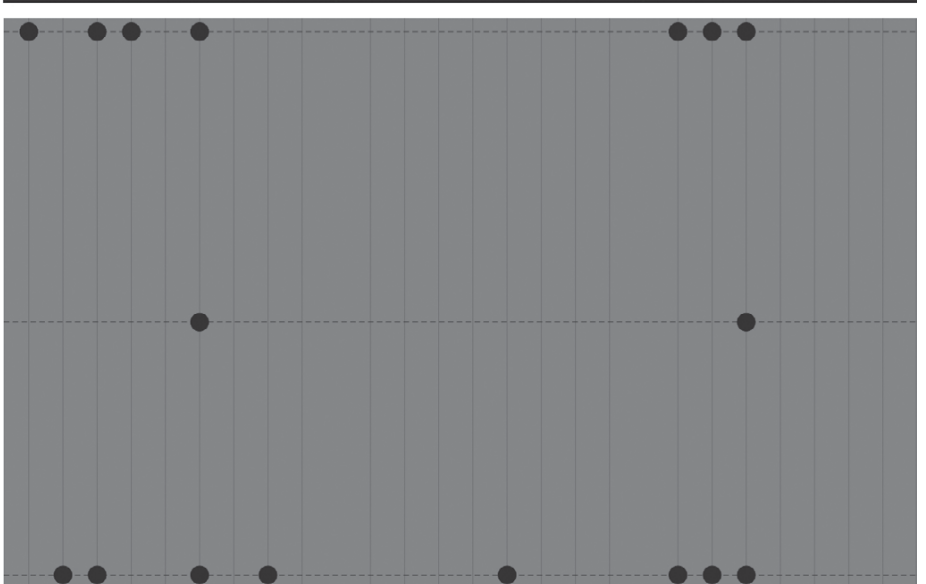
(A1) bedded grey limestone with
chert nodules and marls

A3 thin-bedded, platy cherty

A3) limestones, reddish-grey

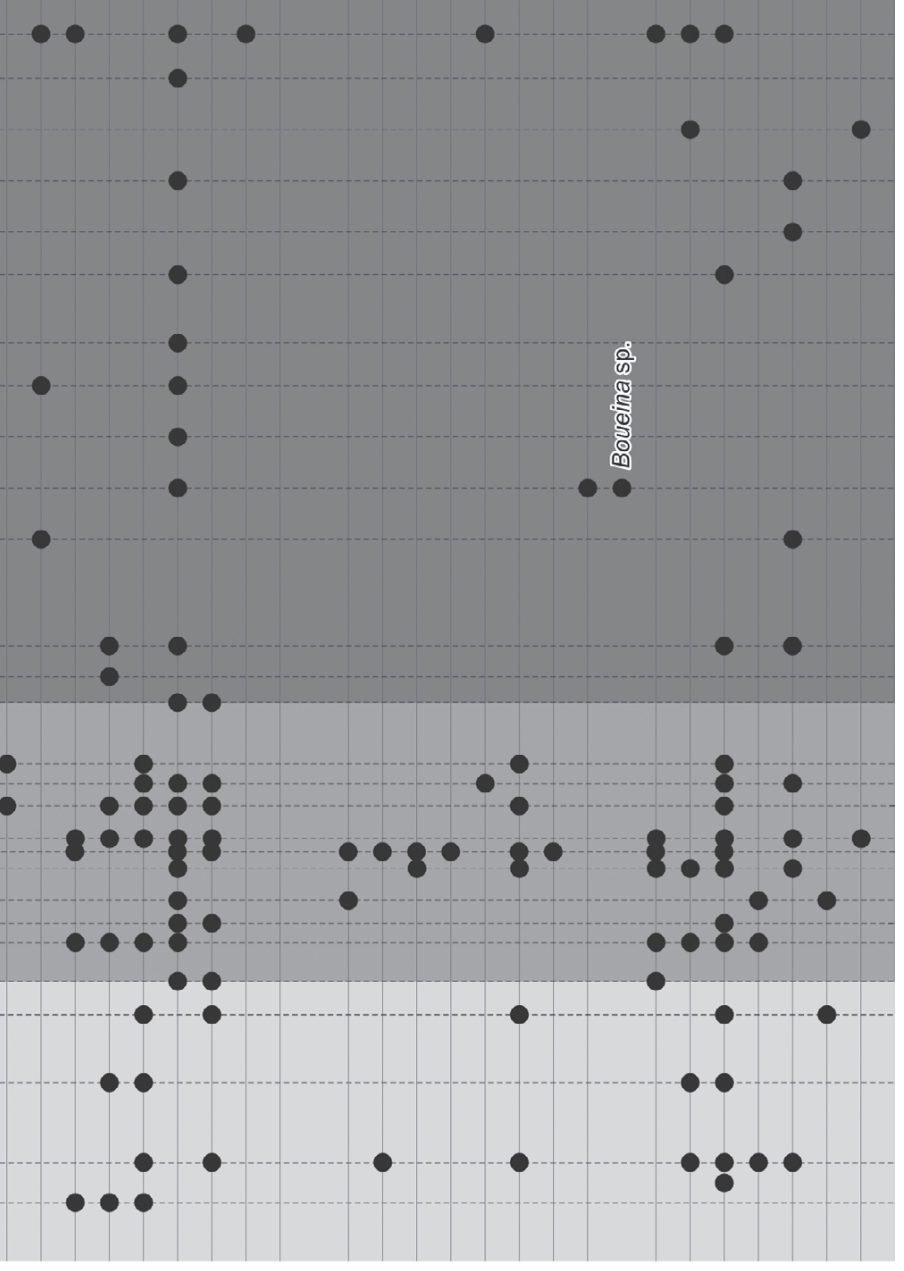

A2 bioturbated greenish-greyish
marly limestones

(B) grey, thick-bedded and

Rectodictyonus giganteus

Rectodictyonus giganteus + Mesorbitolina texana

Mesorbitolina

texana

Figure 4: Detailed section, biostratigraphy and micro- fauna and -flora content. 

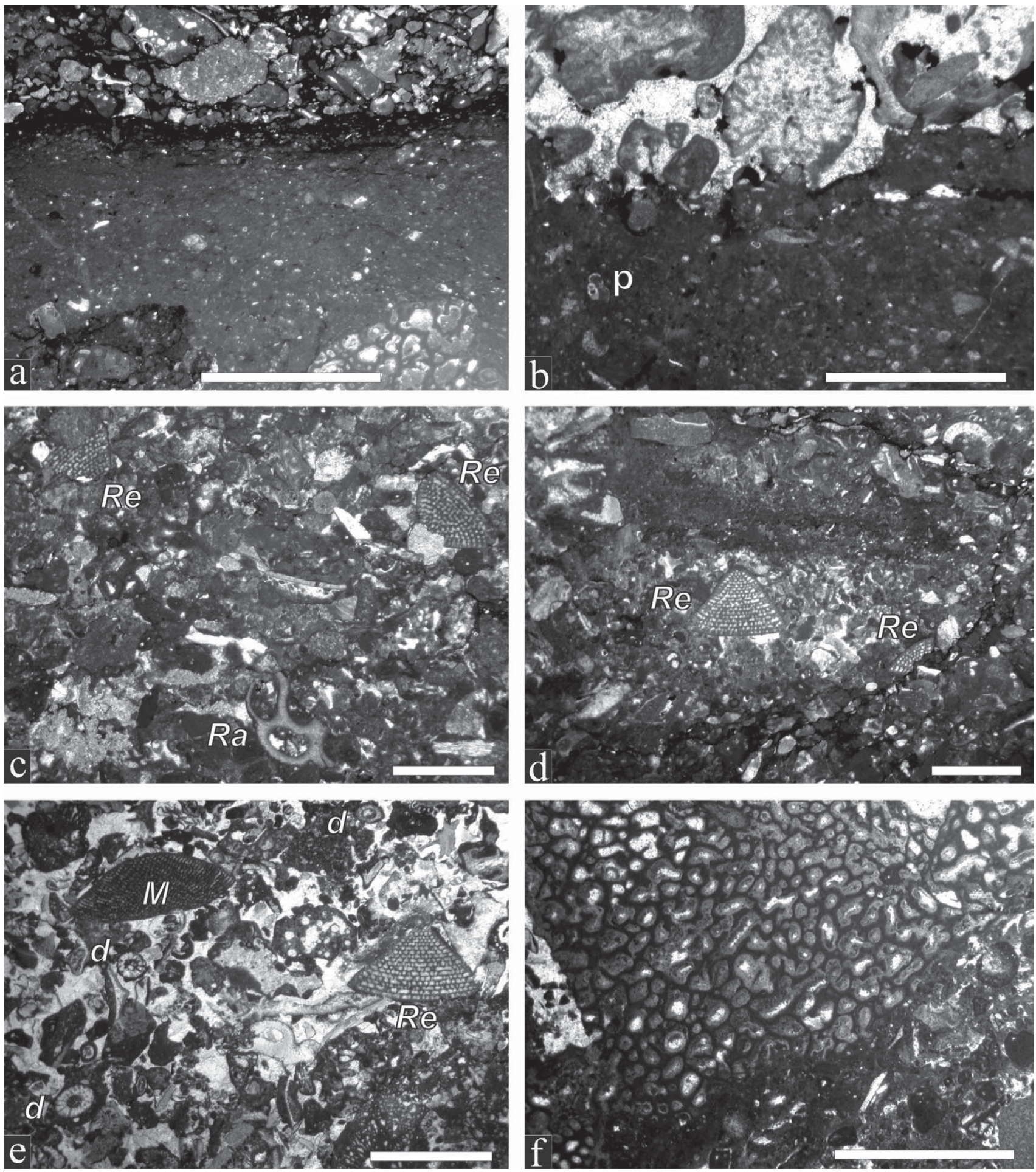

Figure 5: Microfacies of the Aptian resediments. a - Wackestone with some litho- and bio-clasts (here: stromatoporoid skeleton), overlain by a closepacked mass-flow of stylo-breccia or diagenetic packstone habitus (sensu LOGAN \& SEMENIUK 1976). Note the dark layer of styloreactate at the boundary. Sample A 3744. b - Wacke- to packstone containing globigerinid planktonic foraminifera $(p)$ overlain by a grain- to rud-stone with bioclasts of calcareous algae and metazoan skeletons. Sample A 3755-2. c - Packstone with incertae sedis Radiomura cautica SENOWBARI-DARYAN \& SCHÄFER (Ra), Crescentiella morronensis (CRESECENTI), diverse bioclasts and tests of Rectodicytoconus giganteus SCHROEDER (Re). Sample A 3741. d - Mass-flow consisting of close-packed clasts containing dasycladalean algae and tests of Rectodictyoconus giganteus SCHROEDER (Re). Sample Al 976. e-Well washed-out packstone with dasycladalean algae, (D), Mesorbitolina texana (ROEMER) $(M)$ and Rectodictyoconus giganteus SCHROEDER (Re). Sample A 3746-1.f - Massflow deposit with skeleton of the stromatoporoid Tubuliella rotunda TURNŠEK. Sample Al 990.

For a scale bar is $5.0 \mathrm{~mm}$; for $\mathbf{b}-\mathrm{f}$ scale bar is $2.0 \mathrm{~mm}$. 

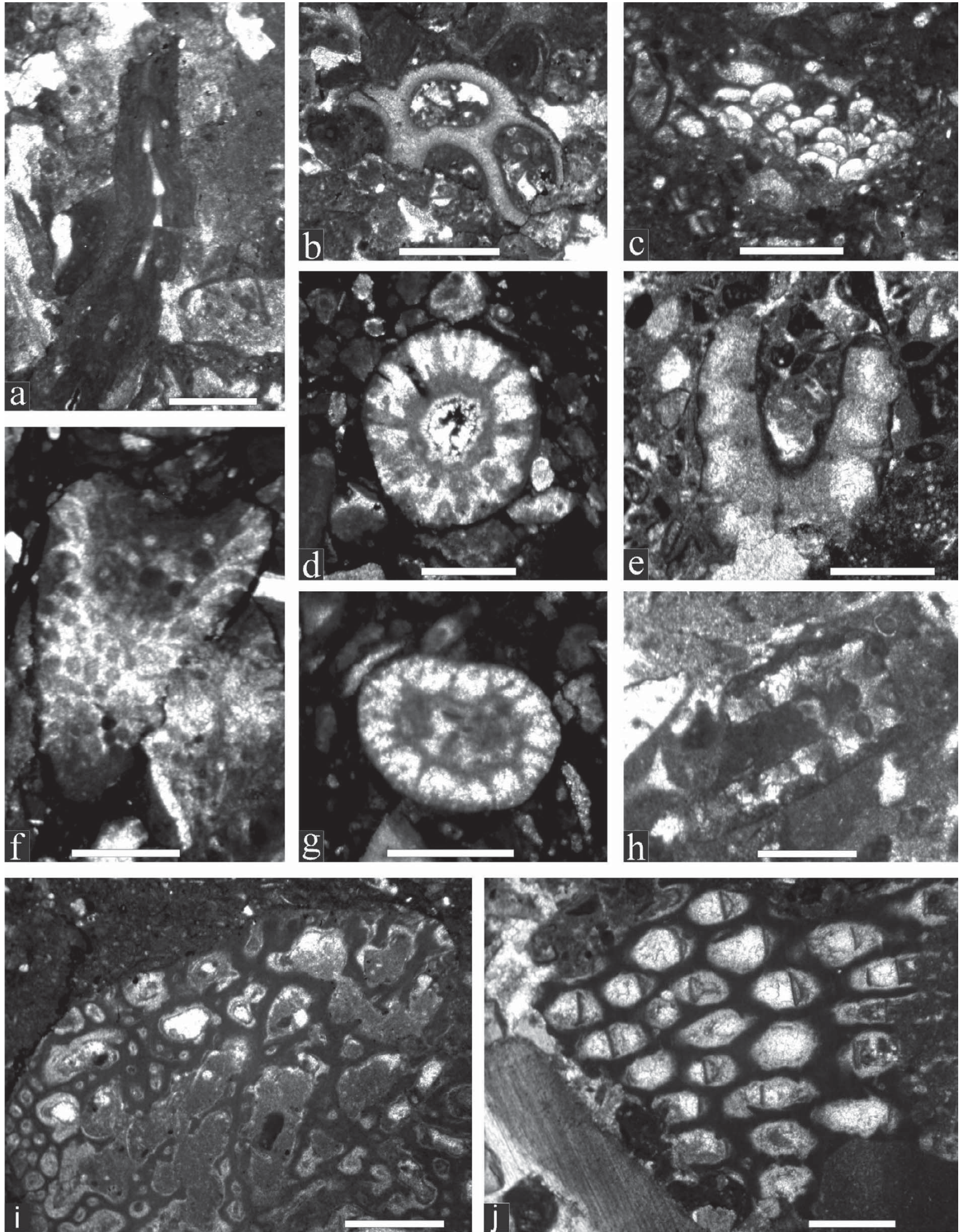

Figure 6: Microproblematica (a-c), dasycladalean algae (d-h) and stromatoporoids (i-j) from the studied section. a) Crescentiella morronensis (CRESCENTI). Sample A 3741. b) Radiomura cautica SENOWBARI-DARYAN \& SCHÄFER. Sample A 3741. c) Koskinobullina socialis CHERCHI \& SCHROEDER. Sample A 3743. d) Acroporella radoicicae PRATURLON. Sample A 3741. f) Salpingoporella pygmaea (GÜMBEL). Sample A 3745. g) Linoporella sp. Sample A 3745. e, h) Steinmanniporella? parsica TAHERPOUR KHALIL ABAD et al. Sample A 3753. i Tubuliella rotunda TURNŠEK. Sample A 3744. j) Tubuliella fluegeli TURNŠEK. Sample A 3748.

For a, c-h scale bar is $0.5 \mathrm{~mm}$; for $\mathbf{b}$, $\mathbf{i}-\mathbf{j}$ scale bar is $1.0 \mathrm{~mm}$ 

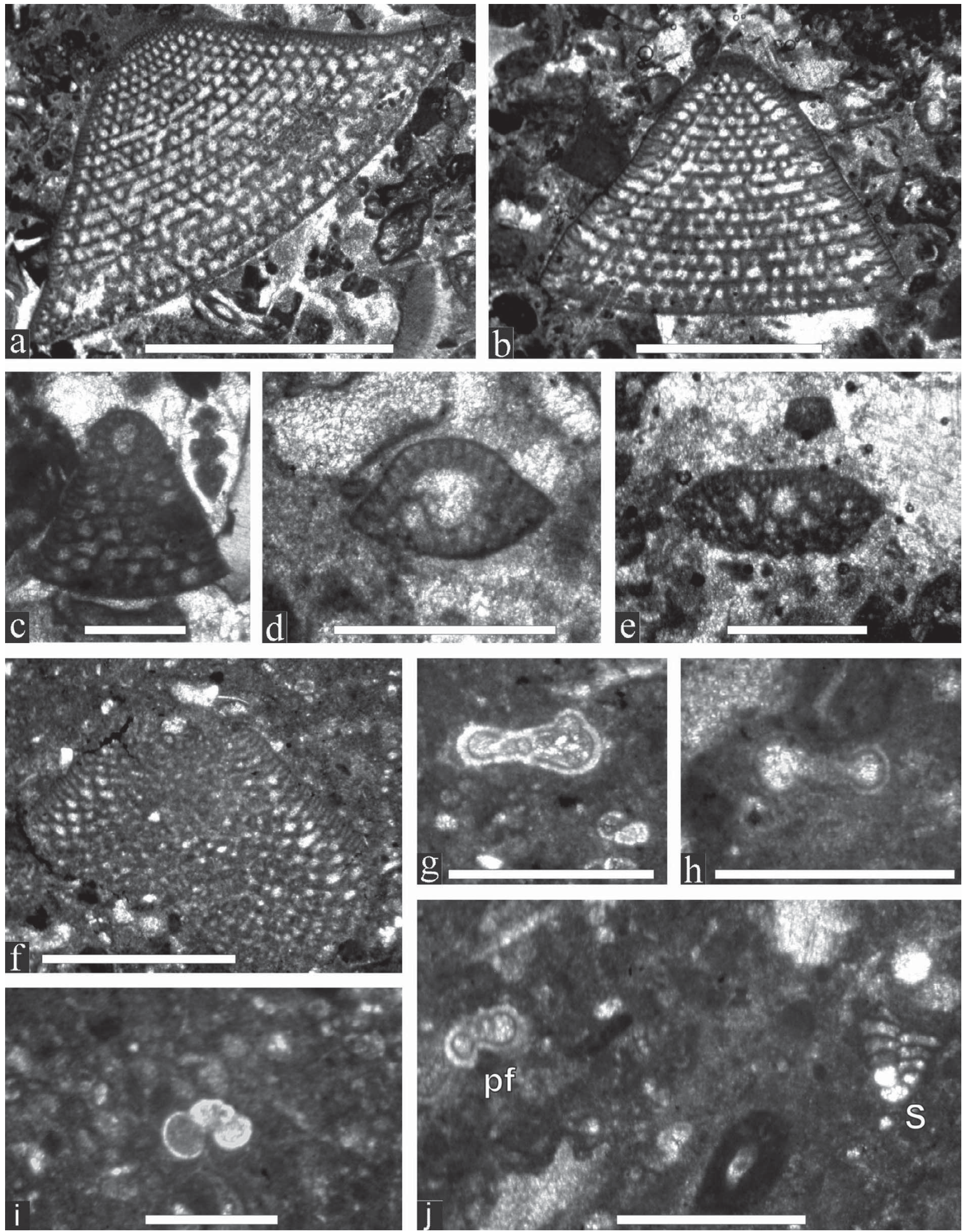

Figure 7: Middle-Late Aptian Foraminifera from the studied section. a-c) Rectodictyoconus giganteus SCHROEDER. Note the centric embryonic apparatus in c; subaxial section of Lenticulina sp. on the right. Samples A 3748, AL 976, A 3476. d-f) Mesorbitolina texana (ROEMER). Samples A 3753, AL 976, g-h) Planispial Globigerinelloides sp., comparable to section of G. algerianus in SLITER (1989, pl. 1/13). Samples A 3753, A 3752. i) Trochospiral globigerinid foraminifer. Sample A 3753. j) Globigernid planktonic foraminifer ( $p f$ ) and Sabaudia minuta (HOFKER) (S). Sample A 3753. For $\mathbf{a}-\mathbf{b}$, $\mathbf{f}$ scale bar is $1 \mathrm{~mm}$; for $\mathbf{c}-\mathbf{e}, \mathbf{g}-\mathbf{j}$ scale bar is $0.5 \mathrm{~mm}$. 


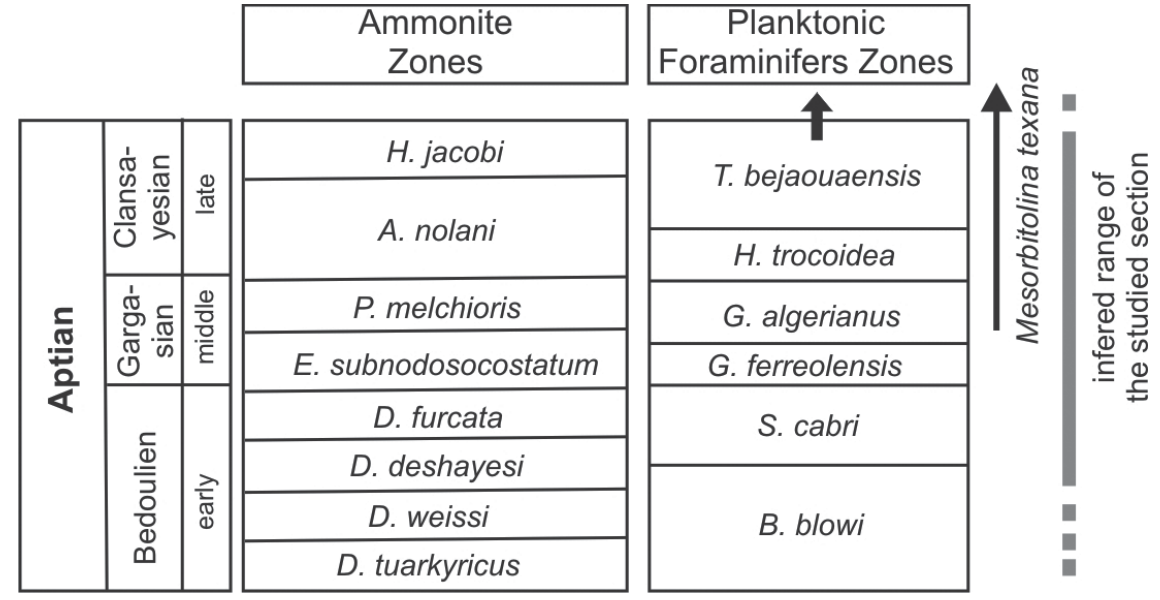

Figure 8: Stratigraphic framework of the studied section (modified after CASTRO et al., 2002). The first appearance of Mesorbitolina texana (ROEMER) at the base of the melchioris ammonite zone refers to SCHROEDER et al. (2010). of older material/clasts seems unlikely. The middle-upper part of the studied section contains only M. texana. Given these results (CASTRO et al., 2002; SCHROEDER et al., 2010 ), the stratigraphic range of $R$. giganteus must be enlarged, comprising at least the late Gargasian. An extension into the earliest Clansayesian seems possible. A possible reason that both taxa are clearly separated at the type-locality of $R$. giganteus might be related to a facies control, as its latest occurrence shows a distinct contemporaneous lithological change from limestones to marls/marly limestones (see fig. 1 in SCHROEDER, 1964). In contrast to Mesorbitolina texana with its numerous records in the literature, Rectodictyonus giganteus represents a rather poorly known taxon, which may account for the limited knowledge of its stratigraphic distribution (see MASSE, 2003).

Although determination of Globigerinelloides in thinsection is problematic (e.g., WEIDICH, 1990), we have to state that our specimens within an interval from sample A-3752 to A-3753 (Fig. 7g-h) are comparable to a section of G. algerianus illustrated by SLITER (1989, pl. 1/13). This species characterizes the G. algerianus zone (MOULLADE, 1966; SLITER, 1989; CASTRO et al., 2002). In summary, the studied section is of Aptian age, assumed to comprise parts of the Bedoulian (Early Aptian) and ranging into the Clansayesian (Late Aptian) (Fig. 8). Whether the top part stretches into the Early Albian is unknown. As only an $18 \mathrm{~m}$ thick sequence below the first occurrence of Mesorbitolina texana exists, extension of the section into the Late Barremian is not very likely. The associated dasycladalean algae are also compatible with an Aptian age (e.g., BUCUR, 1999; TAHERPOUR KHALIL ABAD et al., 2010).

It is worth mentioning that for the carbonate platforms overlying the ophiolites and cropping out in northern Albania, an overall Late Barremian-Early Aptian age has been deduced from micropalaeontological investigations, namely the occurrence of Montseciella arabica (HENSON) (ROBERTSON et al., 2011, tab. 1). As stated by CHERCHI \& SCHROEDER (1999, p. 13), Montseciella arabica "grades into Rectodictyoconus giganteus" during the basal Aptian. $R$. giganteus differs from M. arabica by "the centric position of the embryo and its generally larger test" (op. cit., p. 13). The oblique section of " $M$. arabica" shown by ROBERT-
SON et al. (2011, fig. 6/11), however, does not allow a conclusion to be drawn in this respect. Therefore, this section could also belong to $R$. giganteus in accordance with our results from northern Albania. According to HENSON (1948), the dimensions of Dictyoconus (= Montseciella) arabicus are: test diameter 2.4 to $3.2 \mathrm{~mm}$ and height 1.7 to $2.0 \mathrm{~mm}$. For Rectodictyoconus giganteus SCHROEDER (1964) indicated a test diameter from 4-5 $\mathrm{mm}$ and height of 3-4 $\mathrm{mm}$. Juvenile specimen of $R$. giganteus, clearly evidenced by the central embryo in our material (Fig. 7c, compare also Fig. 4a-4 in SCHROEDER et al., 2010), however falls into the dimensional range of $M$. arabica, so that the pure dimensional discrimination of both taxa remains ambiguous. The situation becomes more complicated as microspheric specimens of $M$. arabica may reach test diameters of up to $6 \mathrm{~mm}$ (Fig. 4b-7 in SCHROEDER et al., 2010). Another point to mention is the fact that no holotype has been indicated for $R$. giganteus in the original description.

Another example refers to the paper of MARRONI et al. (2009), which deals with Early Cretaceous flyschoid deposits in northern Albania. These authors report the occurrence of Paleodictyoconus arabicus (= Montseciella arabica) in turbidite deposits, assigning these, also based on calcareous nannoplankton data, to the Barremian. The figured oblique section of Paleodictyoconus arabicus in MARRONI et al. (2009, fig. 6e) however, does not belong to this taxon. The typical vermicular structural elements in the central zone are absent, and this orbitolinid could be a flat discoidal specimen of Mesorbitolina or Palorbitolina without allowing a species attribution, as the embryonic apparatus is not shown. In any case, a Barremian age based on this orbitolinid section alone is not possible; but we cannot comment on the nannofossil determination. A third example comes from the Vardar zone of Serbia, where "Paleodictyoconus arabicus" was reported by ZELIC et al. (2010, fig. 5c). Furthermore, this oblique section of an orbitolinid foraminifer belongs to Palorbitolina or Mesorbitolina. Last but not least, an undetermined orbitolinid that we refer to as an oblique section of either $M$. arabica (HENSON) or R. giganteus SCHROEDER was figured by CARRAS et al. (2004: P1. 1, Fig. F) from the Pelagonian Unit of Greece. It occurs in resedimented carbonates assigned to the Cenomanian, assuming 
"an hiatus including the whole Early Cretaceous" (op. cit., p. 353). This situation generally mirrors the situation in Albania, where firstly a Late Jurassic carbonate platform overlies the ophiolites, later followed by several emersion phases and at least a Late Cretaceous series. Whether the Early Cretaceous orbitolinid in the Greek case study was reworked from older sediments or whether the age of the "Late Cretaceous" series must be re-assessed is unknown.

In conclusion, stratigraphic data obtained from orbitolinid foraminifera from sediments associated with Dinaric ophiolites reported in the literature, (with or without figuration), must be considered with caution, especially when these determinations are coupled with dating of tectonic or sedimentary events.

\section{DISCUSSION AND CONCLUSIONS}

After the obduction of the Mirdita ophiolites onto the Apulian margin in early Late Jurassic times, subsequent shallowwater carbonates were formed overlying the ophiolite nappes. The first platform, of Kimmeridgian-Tithonian age (Kurbnesh Platform), was eroded before the onset of the second platform in ?Late Berriasian times. The Late Jurassic platform can only be recognized by preserved Late Jurassic basinal deposits (slope sediments) and their erosional products in earliest Cretaceous foreland basin fills (SCHLAGINTWEIT et al., 2008). In-situ platform areas of Late Jurassic age overlying the ophiolites, are not preserved on top of the Mirdita ophiolites. In contrast, the second platform of ?Late Berriasian to Valanginian age (Munella Platform) is partly preserved in central Albania. However the type-locality, the Mali I Munelles, is highly sheared and the platform carbonates are imbricated (SCHLAGINTWEIT et al., 2006). Contemporaneous coarse-grained foreland basin fills, contain clasts of the Munella Platform (SCHLAGINTWEIT et al., 2008). Both platforms were therefore formed under a tectonically active regime after ophiolite emplacement.

After a period of erosion/omission until the Late Barremian, a new cycle of carbonate deposition began in the early Aptian, at the top of the deeply eroded Mirdita nappe pile and its overlying Late Jurassic and Early Cretaceous carbonate platforms. The formation of the Aptian Mali I Shenjtit carbonate platform most probably began in the Early Aptian and not in the Barremian as formerly estimated. In contrast to the older platforms, the sedimentary succession of this platform is not sheared and its layering is flat. After formation of this platform, tectonic movement, most probably the formation of a horst-and-graben structure, must have been established before deposition of the Late Cretaceous (rudist) limestones.

The onset of the Mali I Shenjtit platform and the total thickness of the flat lying shallow-water carbonates up-section, clearly demonstrate a flooding event, triggered more probably by eustatic sea-level changes rather than important tectonic movements. An important sea-level rise is known near the base of the Aptian (e.g., GRADSTEIN et al., 2004), followed by a regression near the end of the Aptian. This fits well with the age range of the Mali I Shenjtit platform, which does not extend beyond the Aptian.
On basis of the analysis of the foreland basin fills and their generally recognizable fining-upward trend (e.g., BORTOLOTTI et al., 1996: "Firza Flysch"), as well as complete erosion of the oldest and the imbrication of the second platform, GAWLICK et al. (2008) considered a decrease in tectonic activity from the Late Jurassic to the Early Cretaceous. The flat lying Aptian shallow-water carbonates fit into the trend, that platform formation in Late Jurassic to Early Cretaceous times become more and more controlled by sea-level fluctuation rather than tectonic motion. This was recently confirmed in general by ROBERTSON et al. (2011).

The onset and demise of the Late Jurassic carbonate platforms after the emplacement of the ophiolite nappe stack in the Oxfordian reflect a decrease in tectonic activity from the Kimmeridgian to the Aptian. Whereas the first platform (Kimmeridian - Tithonian) was rapidly eroded after its formation, most probably as the result of the ongoing tectonic shortening, (compare SCHMID et al., 2008), and also documented by thick foreland basin deposits, the second platform (?Late Berriasian-Valanginian) was formed in a tectonically active regime, but one of decreasing intensity. The younger sedimentary evolution reflects deposition in a regime, which was more imprinted by eustatic sea-level fluctuations than tectonics. The Aptian carbonate platform was formed in a phase of relative tectonic quiescence before a new tectonic cycle (?late Albian/Cenomanian) began. Only these younger tectonic motions - faulting and thrusting -, e.g. in meso-Cretaceous, Palaeogene and/or Neogene times, affected this platform together with its underlying rocks. As a result of the pre-Late Cretaceous faulting, the Mali I Shenjtit platform become eroded over large areas and the ophiolites, particularly the ophiolite mélanges were overlain by early Late Cretaceous rudist Limestones.

\section{ACKNOWLEDGEMENT}

The joint projects "Tectonothermal Evolution of the Albanides 2003-2005" and "emplacement of the copper ore deposits 2006-2007" received financial support from: Albanian Government (Geological Survey of Albania); University of Leoben, University of Vienna, Austrian Academic Exchange Service, all Austria; University of Tübingen, Germany. The careful reviews of Ioan BUCUR (Cluj-Napoca) and Anonymus are gratefully acknowledged. The assistance with the English of Julie ROBSON is kindly acknowledged.

\section{REFERENCES}

BORTOLOTTI, V., KODRA, A., MARRONI, M., MUSTAFA, F., POLFI, L., PRINCIPI, G. \& SACCANI, E. (1996): Geology and Petrology of ophiolite sequences in the Mirdita region (Northern Albania).Ofioliti, 21/1, 3-20.

BUCUR, I.I. (1999): Stratigraphic significance of some skeletal algae (Dasycladales, Caulerpales) of the Phanerozoic.- In: FARINACCI, A. \& LORD, A.R. (eds.): Depositional Episodes and Bioevents. Palaeopelagos Spec. Pub., 2, 53-104.

CARRAS, N., FAZZUOLI, M. \& PHOTIADES, A. (2004): Transition from carbonate platform to pelagic deposition (Mid Jurassic-Late Cretaceous), Vourinos Massif, Northern Greece.- Riv. Ital. Paleont. Strat., 110/1, 345-355. 
CASTRO, J.M., COMPANY, M., DE GEA, G.A. \& AGUADO, R. (2001): Biostratigraphy of the Aptian-Middle Cenomanian platform to basin domain in the Prebetic Zone of Alicante, SE Spain: calibration between shallow water benthonic and pelagic scales.- Cret. Res., 22, 145-156. doi: 10.1006/cres.2000.0249.

CHERCHI, A. \& SCHROEDER, R. (1999): Montseciella, a new orbitolinid genus (Foraminiferida) from the uppermost Hauterivian - Early Barremian.- Treb. Mus. Geol. Barcelona, 8, 5-23.

DILEK, Y., SHALLO, M. \& FURNES, H. (2005): Rift-Drift, Seafloor Spreading, and Subduction Tectonics of Albanian Ophiolites.- International Geology Review, 47, 147-176._doi: 10.2747/0020-6814. 47.2 .147

GAWLICK, H.J., FRISCH, W., HOXHA, L., DUMITRICA, P., KRYSTYN, L., LEIN, R., MISSONI, S. \& SCHLAGINTWEIT, F. (2008): Mirdita Zone ophiolites and associated sediments in Albania reveal Neotethys Ocean origin.-Int. J. Earth Sci., 97, 865-881. doi: 10.1007/ s00531-007-0193-z

GAWLICK, H.-J., MISSONI, S., SCHLAGINTWEIT, F., SUZUKI, H., FRISCH, W., KRYSTYN, L., BLAU, J. \& LEIN, R. (2009): Jurassic Tectonostratigraphy of the Austroalpine domain.- Journal of Alpine Geology, 50, 1-152.

GRANIER, B. \& DELOFFRE, R. (1993): Inventaire critique des algues dasycladales fossiles II Partie - les algues dasycladales du Jurassicssique et du Crétacé.- Rev. Paléobiol., 12, 19-65.

LOGAN, B.W. \& SEMENIUK, V. (1976): Dynamic metamorphism; processes and products in Devonian carbonate rocks, Canning Basin, Western Australia.- Geol. Soc. Australia Spec. Pub., 16, 1-138.

MARRONI, M., PANDOLFI, L., ONUZI, K., PALANDRI, S. \& XHOMO, A. (2009): Ophiolite-bearing Vermoshi flysch (Albanian Alps, Northern Albania): elements for its correlation in the frame of Dinaric-Hellenic belt.- Ofioliti, 34/2, 95-108.

MASSE, J.-P. (2003): Integrated stratigraphy of the Lower Aptian and applications to carbonate platforms: a state of the art.- In: GILI, H.N. \& SKELTON, P.W. (eds.): North African Cretaceous carbonate platform systems, NATO Science Series, IV. Earth and Environmental Sciences, 28, 215-227, Kluwer Academic Publishers.

MILAN, A. (1969): Faziesverhältnisse und Hydrozoenfauna des Malms im Küstenland des nördlichen Velebit und Velika Kapela.- Geol. vjesnik, 22 (1968), 201-219.

MOULLADE, M. (1966): Étude stratigraphique et micropaléontologique du Crétacé inférieur de la « fosse Vocontienne ».- Doc. Lab. Géol. Fac. Sci. Lyon, 15, 1-369.

NOWACK, E. (1928): Geologische Karte von Albanien 1:200.000.- Verlag Kartographisches Institut Wien.

GRADSTEIN, F., OGG, J. \& SMITH, A. (2004): A Geological Time Scale.- Cambridge University Press, Cambridge, 1-589.

PEZA, L.H. \& MARKU, D. (2002): Lower Cretaceous in the Munella Mountains (Mirdita Zone, northeastern Albania).- In: WAGREICH, M. (ed.): Aspects of Cretaceous Stratigraphy and Palaeobiogeography. Österr. Akad. Wiss., Schriftenr. Erdwiss. Komm., 15, 365-372.

PEZA, L.H. \& ZITT, J. (2002): Urgonian (Early Cretaceous) echinoids of the Mirdita Zone (Southeast Albania).- Geol. Carpath., 53/5, 327-332.

ROBERTSON, A. \& SHALLO, M. (2000): Mesozoic-Tertiary tectonic evolution of Albania in its regional Eastern Mediterranean context.Tectonophysics, 316, 197-254. doi: http://dx.doi.org/10.1016/S00401951(99)00262-0

ROBERTSON, A.H.F., IONESCU, C., HOECK, V., KOLLER, F., ONUZI, K., BUCUR, I.I. \& GHEGA, D. (2011): Emplacement of the Jurassic Mirdita ophiolites (southern Albania): evidence from associated clastic and carbonate sediments.- Int. J. Earth Sci. doi 10.1007/s00531-010-0603-5
ROPOLO, P., CONTE, G., MOULLADE, M., TRONCHETTI, G. \& GONNET, R. (2008): The Douvilleiceratidae (Ammonoidea) of the Lower Aptian historical stratotype area at Cassis-Le Bédoule (SE France).- Carnets de Géologie Mem. 3 (CG2008_M03)

SCHLAGINTWEIT, F., GAWLICK, H.J., MISSONI, S., LEIN, R. \& HOXHA, L. (2006): Late Jurassic to Early Cretaceous dasycladales and benthonic foraminifera from the Munella carbonate platform s. 1. of the Mirdita Zone (Albania).- In: SUDAR, M., ERCEGOVAC, M. \& GRUBIC, A. (eds.): Proceedings XVIIIth Congress of Carpathian-Balkan Geological Association), 527-530, (National committee of the Carpathian - Balkan Geological Association; Serbian Geological Society) Belgrade.

SCHLAGINTWEIT, F., GAWLICK, H.J., MISSONI, S., HOXHA, L., LEIN, R. \& FRISCH, W. (2008): The eroded Late Jurassic Kurbnesh carbonate platform in the Mirdita Ophiolite Zone of Albania and its bearing on the Jurassic orogeny of the Neotethys realm.Swiss J. Geosci., 101, 125-138. doi: 10.1007/s00015-008-1254-4

SCHMID, S.M., BERNOULLI, D., FÜGENSCHUH, B., MATENCO, L., SCHEFER, S., SCHUSTER, R., TISCHLER, M. \& USTASZEWSKI, K. (2008): The Alpine-Carpathian-Dinaride-orogenic system: correlation and evolution of tectonic units.-Swiss J. Geosci. (Eclogae Geol. Helv.), 101, 139-183. doi: 10.1007/s00015-008-1247-3

SCHROEDER, R. (1964): Orbitoliniden-Biostratigraphie des Urgons nordöstlich von Teruel (Spanien).- N. Jb. Geol. Paläont. Mh., 1964, 462-472.

SCHROEDER, R. (1975): General evolutionary trends in Orbitolinas.Rev. esp. Micropaleont., num. spec., 117-128.

SCHROEDER, R. (1985): Orbitolina (M.) texana (ROEMER, 1849).In: SCHROEDER, R. \& NEUMANN, M. (eds.): Les grands Foraminifères du Crétacé Moyen de la région Méditerranénne. Géobios Mém. Spéc., 7, 77-80.

SCHROEDER, R., CLAVEL, B., CHERCHI, A., BUSNARDO, R., CHAROLLAIS, J. \& DECROUEZ, D. (2002): Lignées phylétiques d'Orbitolinidés de l'intervalle Hauterivien supérieur-Aptien inférieur; leur importance stratigraphique.- Rev. Paléobiol., 21, 853-863.

SCHROEDER, R., VAN BUCHEM, F.S.P., CHERCHI, A., BAGHBANI, D., VINCENT, B., IMMENHAUSER, A. \& GRANIER, B. (2010): Revised orbitolinid biostratigraphic zonation for the Barremian Aptian of the eastern Arabian Plate and implications for regional stratigraphic correlations.- GeoArabia Spec. Pub., 4, 49-96.

SLITER, W.V. (1989): Biostratigraphic zonation for Cretaceous planktonic foraminifers examined in thin section.- J. Foramin. Res., 19, 1-19. doi: 10.2113/gsjfr.19.1.1

TAHERPOUR KHALIL ABAD, M., CONRAD, M.A., ARYAEI, A.A. \& ASHOURI, A.R. (2010): Barremian-Aptian Dasycladalean algae, new and revisited, from the Tigran Formation in the Kopet Dagh, NE Iran.- Carnets de Géologie - Notebooks on Geology, Article 2010/05 (CG2010 A05)

TURNŠEK, D. (1966): Upper Jurassic hydrozoan fauna from southern Slovenia.- Razprave Razr. SAZU, 9, 335-428.

TURNŠEK, D. (1969): A contribution to the palaeoecology of Jurassic Hydrozoa from Slovenia.- Razprave Razr. SAZU, 12, 209-237.

TURNŠEK, D., BUSER, S. \& OGORELEC, B. (1981): An Upper Jurassic reef complex from Slovenia, Yugoslavia.- SEPM Spec. Pub., 30, 361-169.

VELIĆ, I. (2007): Stratigraphy and palaeobiogeography of Mesozoic benthic foraminifera of the Karst Dinarides (SE Europe).- Geol. Croat., 60, 1-113.

WEIDICH, K.F. (1990): Die kalkalpine Unterkreide und ihre Foraminiferenfauna.- Zitteliana, 17, 1-312.

XHOMO, A., KODRA, A., DIMO, L1., XHAFA, Z., NAZAJ, SH., NAKUÇI, V., YZEIRAJ, D., LULA, F., SADUSHI, P., SHALLO, M., 
VRANAJ, A. \& MELO, V. (2002): Harta gjeologjike e Shqiperise, Geological map of Albania, scale 1:200,000, published by the Ministry of Industry and Energy, Republic of Albania.
ZELIC, M., MARRONI, M., PANDOLFI, L. \& TRIVIC, B. (2010): Tectonic setting of the Vardar suture zone (Dinaric-Hellenic belt): the example of the Kopaonik area (southern Serbia).- Ofioliti, 35/1, 49-69.

Manuscript received May 04, 2011

Revised manuscript accepted November 15, 2011

Available online February 25, 2012 